\title{
Assessment of production objective and breeding practices of rural goat keepers and implications for a breeding programme in north central Nigeria \\ *Yakubu, A. and Achapu, M. M.
}

Department of Animal Science, Faculty of Agriculture, Nasarawa State University, Keffi, Shabu-Lafia Campus, P.M.B. 135, Lafia, Nasarawa State, Nigeria.

*Corresponding author's email address: abdulmojyak@gmail.com

\begin{abstract}
Goat farming is a veritable source of livelihood of many rural families in Africa. This study aimed at determining prevailing production systems and breeding objectives of rural goat producers in north central Nigeria. A total of 180 rural goat keepers corresponding to 60 per State (Nasarawa, Benue and Plateau) were randomly sampled. Primary data (socioeconomics of respondents, reasons for keeping goats, flock structure, management system, productivity and breeding practices) were collected through individual structured questionnaire administration. Cross tabulations and Chi square ( $\chi 2)$ statistics were used to compare categorical variables, while rank means, arithmetic means and standard deviations were calculated for within- and between-state comparisons of the continuous variables. While more goat producers were involved in crop farming in Benue State (43.6\%), only 34.5 and $21.8 \%$ engaged in farming in Plateau and Nasarawa State, respectively. Goats were kept for income generation, milk, meat and cultural/religious functions by about 61.1, 12.8, 15.0 and $6.1 \%$ of the producers while the relative importance given by respondents to the different objectives varied significantly (Chi-square $=6.62 ; P<0.05)$ across the States. The

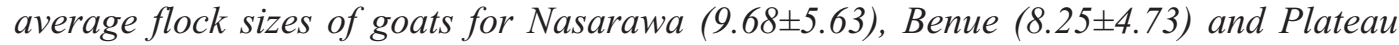

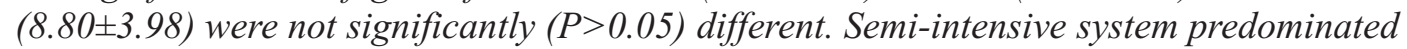
$(P<0.01)$. Productivity indices showed that for age of parturition, number of kids of Sahel doe and lifespan of goats, there was no significant difference $(P>0.05)$. Among all the breeding traits across the three States, only disease resistance varied $(P<0.01)$. Disease resistance, survival, fertility, number of offspring and body size appeared similar $(P>0.05)$ as preference for production traits. However, growth (83.52-97.68 mean ranks) (Plateau State) and cultural importance (75.28-104.70 mean ranks) (Benue State) varied across the States $(P<0.05$ and $P<0.01$, respectively). The present information will be useful in understanding the farmers' production objectives, management and breeding practices as a first step in designing a sustainable breeding programme for rural farmers in the study areas.
\end{abstract}

Keywords: Goats, management, breeding, productivity, Nigeria

\section{Introduction}

Goat production over the years is one of the major means of improving the livelihoods of poor livestock keepers, reducing poverty and attaining sustainable agriculture and universal food security (Abdul Aziz, 2010; Yakubu et al., 2010; 2011; Abegaz et al., 2013). The population of goats in Nigeria is estimated at 53.8 million (FAOSTAT, 2011) of which traditionally reared stock contributes $99.97 \%$, while $0.03 \%$ of the stock is commercially managed.

However, goat production in north central of Nigeria is constrained by many biological, environmental and socioeconomical factors. Among them, inadequacy/lack of systematic breeding programs is an important constraint. There is no systematic goat breeding program in place and goat is the most neglected livestock species in research and development endeavours (Tsegahun et al., 
2000). There have been a few attempts of genetic improvement program of goats through upgrading the exotic genetic blood levels. However, it was reported that crossbred goats did not perform better than indigenous goats if both groups were kept at similar management levels (Ayalew et al., 2003). Pure breeding applying community based breeding program is believed to be a more appropriate breeding program for such type of production systems which are characterized as low-input system with poorly developed infrastructures (Gizaw et al., 2009; Haile et al., 2011). There is inadequate understanding of the genetic potentialities and capabilities of Nigerian goats as well as the associated productive factors. Over the year, this has hampered the development of the technical packages for increasing goat productivity (Otuma, 2003). There is need to conserve the good genes of the local goats that are able to strive and survive so as not to lose ground on holding well onto the economy and also ensure availability of enough goat meat in the country.

The general objective of the study was to assess the management practices involved in rural goat production in north central Nigeria to better understand the prevailing production systems and breeding objectives for enhancing goat research/breeding programmes in north central Nigeria.

\section{Materials and Methods \\ Description of study area}

The study was carried out in three states of north central Nigeria: Nasarawa, Benue and Plateau. Two local government areas were sampled in each state. Nasarawa State falls within the Guinea savannah agroecological zone and is found between latitudes $7^{\circ} 52^{\prime} \mathrm{N}$ and $8^{\circ} 56^{\prime} \mathrm{N}$ and longitudes $7^{\circ} 25^{\prime} \mathrm{E}$ and $9^{\circ} 37^{\prime} \mathrm{E}$ respectively (Lyam, 2007). Benue State lies within the lower river Benue trough in north central Nigeria. Its geographic coordinates are longitude 7 $47^{\prime}$ and $10^{\circ} 0^{\prime}$ east; Latitude $6^{\circ} 25^{\prime}$ and $8^{\circ}$ $8^{\prime}$ north. Plateau State is located between latitude $80^{\circ} 24^{\prime}$ North and longitude $80^{\circ} 32^{\prime}$ and $100^{\circ} 38$ east. The altitude ranges from 1,200 meters (400 feet) to a peak of 1,829 meters above sea level in the Shere Hills, near Jos.

\section{Sampling procedure}

Rural goat keepers were selected from the study area (Plateau, Nasarawa and Benue States in north central zone of Nigeria) based on goat production potential and willingness of the farmers to participate in the study. Two local government areas (LGA) were randomly selected in each State. A total of 180 rural goat keepers corresponding to 30 per LGA and 60 per State were randomly sampled.

\section{Data collection procedure}

The questionnaires were used to elicit information on the socio-economic characteristics of the respondents, reasons for keeping goats, livestock ownership, flock sizes and structure, knowledge on the husbandry practices, breeding practices and selection criteria for breeding females and males. Respondents were asked to list the production objectives and rank the most important. Selection criteria for breeding females and males were also ranked from the most important (1) to the least important (4). The questionnaires were pre-tested on 10 goat farmers in each State to ensure that the questions were adapted to local conditions without affecting the comparability of information across locations. The interviews were conducted in each site-specific local language with the assistance of local enumerators.

\section{Statistical analysis}

Descriptive statistics were performed for all variables. Cross tabulations and Chi square $(\chi 2)$ statistics were used to compare 
categorical variables within and between states, while rank means and arithmetic means and their standard deviations were calculated for within- and between-state comparisons of the continuous variables. Within each state, comparisons of mean ranks were performed using the Friedman test, which compares the distribution of preference ranks of each animal function and of each selection criterion. Post hoc analyses were then applied using the nonparametric Wilcoxon Signed-rank test with Bonferroni's adjustments. The nonparametric Kruskal-Wallis test followed by the Mann-Whitney U test for post hoc separation of group means and mean ranks was used for comparison between states. A statistically significant difference was reported if the $p$ value is less than 0.05 . SPSS (2010) statistical package was employed.

\section{Results}

Socio-economic characteristics of farmers More males (37.4\%) were found in Benue State while the female respondents were more in Nasarawa State (43.9\%), although not significantly different $(\mathrm{P}>0.05)$ (Table 1). Majority of the households were married (92.22\%) while more singles $(61.5,53.5$ and $0.0 \%$, respectively) were observed $(\mathrm{P}<0.05)$ in Benue and Nasarawa compared to Plateau State. The primary occupation of the households varied from one State to another $(\mathrm{P}<0.001)$. While more goat producers $(43.6 \%)$ were involved in crop farming in Benue State, only 34.5 and $21.8 \%$ engaged in farming in Plateau and Nasarawa State, respectively. However, more households were involved in trading in Nasarawa (44.7\%) compared to $15.8 \%$ in Benue State. Only 14, 9 and 16 individuals $(\mathrm{P}>0.05)$ had access to credit facilities in Nasarawa, Benue and Plateau States, respectively. The average age of respondents was significantly $(\mathrm{P}<0.05)$ higher in Plateau (45.85 \pm 6.11$)$ than Benue and Nasarawa States $(40.17 \pm 9.38$ and $38.28 \pm 10.56$, respectively). There was no significant difference $(\mathrm{P}>0.01)$ in the average household size in the three States. However, households in Plateau State had significantly $(\mathrm{P}<0.05)$ more years of goat experience $(9.06 \pm 4.42)$ compared to their counterparts (7.22 \pm 4.41 and 7.20 \pm 4.53$)$.

\section{Reasons for goat keeping}

119 (61.1), 23 (12.8), 27 (15.0) and 11 (6.1\%) kept goats for income generation, milk, meat and cultural/religious functions, respectively in Nasarawa, Benue and Plateau States (Figure 1). The relative importance given by respondents to the different production objectives varied significantly (Chi-square $=6.62 ; \mathrm{P}<0.05$ ) across the States.

\section{Flock composition}

The average flock size of goats for Nasarawa (9.68 \pm 5.63$)$, Benue $(8.25 \pm 4.73)$ and Plateau $(8.80 \pm 3.98)$ was not significantly $(\mathrm{P}>0.05)$ different from one another. Across the three States, West African dwarf goats were the most reared animals (mean flock size of $7.17 \pm 4.76$, $6.93 \pm 4.09$ and $7.85 \pm 3.95$ for Nasarawa, Benue and Plateau States, respectively) while Sahel goats were the least kept (Table 2).

Foundation stock and systems of management of goats

Most of the foundation stock were purchased from the markets and neighbourhoods, and cut across $(\mathrm{P}>0.05)$ the three States. The management system varied across $(\mathrm{P}<0.01)$ the three States, where semi-intensive system predominated and was more practiced (39.3 and 34.8\%, respectively) in Plateau and Nasarawa States. A good number $(82.78 \%)$ of the households had access to veterinary personnel which varied $(\mathrm{P}<0.01)$ from location one to another (Table 3 ). 
Assessment of production objective and breeding practices of rural goat keepers and implications for a breeding programme in north central Nigeria

Table 1: Socio economic characteristics of goat keepers in Nasarawa, Benue and Plateau States

\begin{tabular}{|c|c|c|c|c|c|}
\hline Characteristics & $\begin{array}{l}\text { Nasarawa } \\
\text { No }(\%)\end{array}$ & $\begin{array}{l}\text { Benue } \\
\text { No }(\%)\end{array}$ & $\begin{array}{l}\text { Plateau } \\
\text { No }(\%)\end{array}$ & Pearson Chi-square & Significance \\
\hline \multicolumn{6}{|l|}{ Categorical variables } \\
\hline \multicolumn{6}{|l|}{ Sex } \\
\hline Male & $35(28.5)$ & $46(37.4)$ & $42(34.1)$ & & \\
\hline Female & $25(43.9)$ & $14(24.6)$ & $18(31.6)$ & 4.78 & 0.09 \\
\hline \multicolumn{6}{|l|}{ Marital status } \\
\hline Married & $55(31.1)$ & $51(30.7)$ & $60(36.1)$ & & \\
\hline Single & $5(35.5)$ & $8(61.5)$ & $0(0.0)$ & & \\
\hline Widowed & $0(0.0)$ & $1(100.0)$ & $0(0.00)$ & 10.27 & $0.036^{*}$ \\
\hline \multicolumn{6}{|l|}{ Education } \\
\hline None & $26(35.1)$ & $22(29.7)$ & $26(35.1)$ & & \\
\hline Primary & $23(33.3)$ & $24(34.8)$ & $22(31.9)$ & & \\
\hline Secondary & $10(31.2)$ & $13(40.6)$ & $9(28.1)$ & & \\
\hline Tertiary & $1(20.0)$ & $1(20.0)$ & $3(60.0)$ & 2.93 & 0.82 \\
\hline \multicolumn{6}{|l|}{ Primary occupation } \\
\hline Crop farming & $12(21.8)$ & $24(43.6)$ & $19(34.5)$ & & \\
\hline Trading & $34(44.7)$ & $12(15.8)$ & $30(39.5)$ & & \\
\hline Artisan & $0(0.0)$ & $3(100.0)$ & $0(0.0)$ & & \\
\hline Civil service & $12(31.6)$ & $15(39.5)$ & $11(28.9)$ & & \\
\hline Others & $2(25.0)$ & $6(75)$ & $0(0.0)$ & 28.49 & $0.000 * *$ \\
\hline \multicolumn{6}{|l|}{ Access to credit } \\
\hline No & $46(32.6)$ & $51(36.2)$ & $44(31.2)$ & & \\
\hline Yes & $14(35.9)$ & $9(23.1)$ & $16(41.0)$ & 2.55 & 0.28 \\
\hline \multicolumn{6}{|l|}{ Non categorical } \\
\hline & Mean \pm SD & Mean \pm SD & Mean \pm SD & & \\
\hline Age of respondent & $38.28 \pm 10.56^{\mathrm{b}}$ & $40.17 \pm 9.38^{b}$ & $45.85 \pm 6.11^{\mathrm{a}}$ & & \\
\hline Household size & $7.08 \pm 3.97^{\mathrm{a}}$ & $6.47 \pm 8.58^{\mathrm{a}}$ & $6.98 \pm 2.29^{\mathrm{a}}$ & & \\
\hline No of wives & $1.22 \pm 0.78^{\mathrm{a}}$ & $0.85 \pm 0.52^{\mathrm{b}}$ & $1.07 \pm 0.61^{\mathrm{ab}}$ & & \\
\hline No of male children & $2.68 \pm 1.83^{\mathrm{a}}$ & $1.98 \pm 1.55^{\mathrm{b}}$ & $2.27 \pm 1.07^{\mathrm{ab}}$ & & \\
\hline No of female children & $2.20 \pm 1.78^{\mathrm{a}}$ & $1.35 \pm 1.30^{\mathrm{b}}$ & $2.18 \pm 1.44^{\mathrm{a}}$ & & \\
\hline No of dependants & $0.30 \pm 0.74$ & $0.67 \pm 1.62$ & $1.38 \pm 1.15$ & & \\
\hline Experience (years) & $7.20 \pm 4.53^{b}$ & $7.22 \pm 4.41^{\mathrm{b}}$ & $9.06 \pm 4.42^{\mathrm{a}}$ & & \\
\hline
\end{tabular}

$\mathrm{SD}=$ Standard deviation

Means followed by different uppercase letters in rows are different $(\mathrm{P}<0.05)$

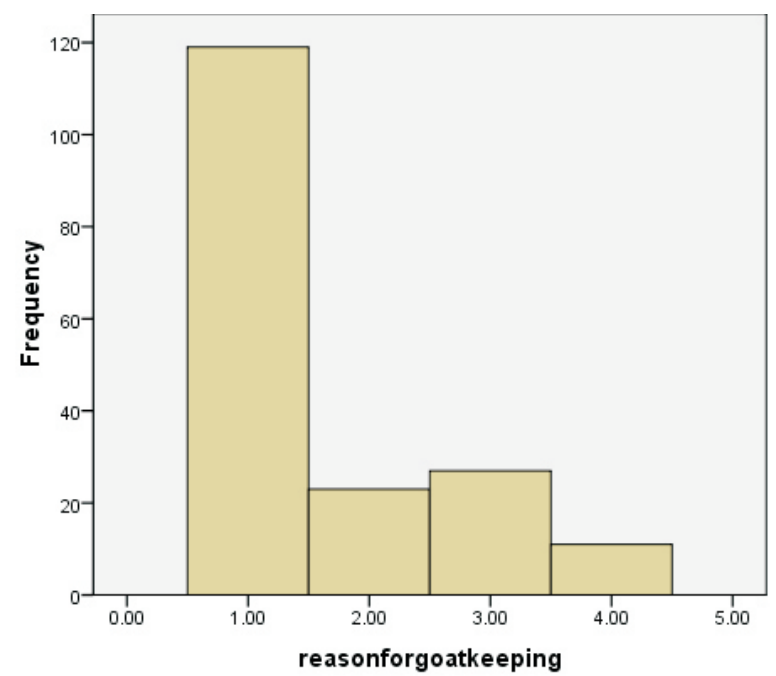

Mean $=1.61$
Std. Dev. $=0.954$
$N=180$

Figure 1. Reasons for keeping goats in Nasarawa, Benue and Plateau States

$1=$ for cash; 2 = for milk, 3 = for meat; $4=$ for cultural/religious obligations 
Yakubu and Achapu

Table 2: Flock structure of goats kept in the Nasarawa, Benue and Plateau States, north central Nigeria

\begin{tabular}{llll}
\hline Genetic group & $\begin{array}{l}\text { Nasarawa } \\
\text { Mean } \pm \text { SD }\end{array}$ & $\begin{array}{l}\text { Benue } \\
\text { Mean } \pm \text { SD }\end{array}$ & $\begin{array}{l}\text { Plateau } \\
\text { Mean } \pm \text { SD }\end{array}$ \\
\hline Flock size & $9.68 \pm 5.63^{\mathrm{a}}$ & $8.25 \pm 4.73^{\mathrm{a}}$ & $8.80 \pm 3.98^{\mathrm{a}}$ \\
West African dwarf & $7.17 \pm 4.76^{\mathrm{a}}$ & $6.93 \pm 4.09^{\mathrm{a}}$ & $7.85 \pm 3.95^{\mathrm{a}}$ \\
Red Sokoto & $1.37 \pm 3.11^{\mathrm{a}}$ & $0.13 \pm 1.03^{\mathrm{b}}$ & $0.77 \pm 2.38^{\mathrm{ab}}$ \\
Sahel & $0.85 \pm 3.32^{\mathrm{a}}$ & $0.12 \pm 0.90^{\mathrm{b}}$ & $0.00 \pm 0.00^{\mathrm{b}}$ \\
Mixed breed & $0.30 \pm 1.33^{\mathrm{a}}$ & $0.80 \pm 2.41^{\mathrm{a}}$ & $0.18 \pm 1.03^{\mathrm{a}}$ \\
\hline
\end{tabular}

$\mathrm{SD}=$ Standard deviation

Means followed by different uppercase letters in rows are different $(\mathrm{P}<0.05)$

Table 3: Management systems of goats kept in the Nasarawa, Benue and Plateau States, north central

\begin{tabular}{|c|c|c|c|c|c|}
\hline Characteristics & $\begin{array}{l}\text { Nasarawa } \\
\text { No }(\%)\end{array}$ & $\begin{array}{l}\text { Benue } \\
\text { No }(\%)\end{array}$ & $\begin{array}{l}\text { Plateau } \\
\text { No }(\%)\end{array}$ & Pearson Chi-square & Significance \\
\hline \multicolumn{6}{|l|}{ Source of stock } \\
\hline Inherited & $3(30.0)$ & $5(50.0)$ & $2(20.0)$ & & \\
\hline Market & $33(39.8)$ & $31(37.3)$ & $19(22.9)$ & & \\
\hline Neighbourhood & $20(25.6)$ & $23(29.5)$ & 35 (44.9) & & \\
\hline Borrowed & $4(44.4)$ & $1(11.1)$ & $4(44.4)$ & 12.39 & 0.054 \\
\hline \multicolumn{6}{|c|}{ Management system } \\
\hline Semi-intensive & $47(34.8)$ & $35(25.9)$ & $53(39.3)$ & & \\
\hline Intensive & $2(25.0)$ & $4(50.0)$ & $2(50.0)$ & & \\
\hline Extensive & $11(29.7)$ & $21(56.8)$ & $5(13.5)$ & 15.33 & $0.004 * *$ \\
\hline \multicolumn{6}{|l|}{ Access to vet } \\
\hline No & $16(51.6)$ & $3(9.7)$ & $12(38.7)$ & & \\
\hline Yes & $44(29.5)$ & $57(38.3)$ & $48(32.2)$ & 10.37 & $0.006 * *$ \\
\hline
\end{tabular}

\section{Productivity parameters of goats}

Productivity indices of goats kept in the Nasarawa, Benue and Plateau States showed that for the age of parturition $(1.01 \pm 0.04, \quad 1.00 \pm 0.00$ and $1.00 \pm 0.00$, respectively), number of kids of Sahel doe $(3.32 \pm 1.19,2.67 \pm 1.51$ and $3.90 \pm .99$, respectively) and lifespan of goats in the study areas, there were no significant difference $(\mathrm{P}>0.05)$. There was also no significant differences $(\mathrm{P}>0.05)$ in the number of kids per WAD for Benue and Plateau States, respectively (Table 4). However, more RS kids were produced in Plateau compared to the two other States. More MB kids (3.30 \pm 0.67 versus $2.48 \pm .92)$ were also found in Plateau than Nasarawa State. The lifespan of goat (7.37 \pm 0.71 , $7.28 \pm 0.64$ and $7.33 \pm 0.77$, respectively) appeared similar $(\mathrm{P}<0.05)$ in all the States.

Table 4: Productivity indices of goats kept in the Nasarawa, Benue and Plateau States, north central Nigeria

\begin{tabular}{llll}
\hline Indices & $\begin{array}{l}\text { Nasarawa } \\
\text { Mean } \pm \text { SD }\end{array}$ & $\begin{array}{l}\text { Benue } \\
\text { Mean } \pm \text { SD }\end{array}$ & $\begin{array}{l}\text { Plateau } \\
\text { Mean } \pm \text { SD }\end{array}$ \\
\hline Age at first parturition & $1.01 \pm 0.04^{\mathrm{a}}$ & $1.00 \pm 0.00^{\mathrm{a}}$ & $1.00 \pm 0.00^{\mathrm{a}}$ \\
Number of kids per WAD doe & $4.05 \pm 1.27^{\mathrm{a}}$ & $3.73 \pm 1.24^{\mathrm{ab}}$ & $3.49 \pm 1.17^{\mathrm{b}}$ \\
Number of kids per RS doe & $3.12 \pm 1.24^{\mathrm{b}}$ & $2.68 \pm 1.20^{\mathrm{b}}$ & $3.88 \pm .89^{\mathrm{a}}$ \\
Number of kids per SH doe & $3.32 \pm 1.19^{\mathrm{a}}$ & $2.67 \pm 1.51^{\mathrm{a}}$ & $3.90 \pm .99^{\mathrm{a}}$ \\
Number of kids per MB doe & $2.48 \pm .92^{\mathrm{b}}$ & $3.11 \pm 1.27^{\mathrm{ab}}$ & $3.30 \pm 0.67^{\mathrm{a}}$ \\
Lifespan & $7.37 \pm 0.71^{\mathrm{a}}$ & $7.28 \pm 0.64^{\mathrm{a}}$ & $7.33 \pm 0.77^{\mathrm{a}}$ \\
\hline
\end{tabular}

$\mathrm{WAD}=$ West African dwarf $; \mathrm{RS}=$ Red Sokoto; $\mathrm{SH}=$ Sahel; $\mathrm{MB}=$ Mixed breed

$\mathrm{SD}=$ Standard deviation; Means bearing different uppercase letters in rows are significantly different $(\mathrm{P}<0.05)$ 


\section{Choice of breeding traits within States}

Number of offspring (4.19), disease resistance (4.20), body size (4.28), survival (4.42), fertility (4.48), mothering ability (4.78) and body conformation (4.79) were highly ranked $(\mathrm{P}<0.05)$ in Nasarawa State.
However, body size, no of offspring, fertility, survival and mothering ability were the most preferred traits for breeding stock in Benue State. In Plateau State, body size, no of offspring, disease resistance, survival and fertility were more highly rated (Table 5).

Table 5: Mean ranks of factors preferred in the choice of breeding stock of goats and their significant level according to Friedman test*

\begin{tabular}{llll}
\hline Traits & $\begin{array}{l}\text { Nasarawa } \\
\text { Mean rank }\end{array}$ & $\begin{array}{l}\text { Benue } \\
\text { Mean rank }\end{array}$ & $\begin{array}{l}\text { Plateau } \\
\text { Mean rank }\end{array}$ \\
\hline Body size & $4.28^{\mathrm{a}}$ & $4.39^{\mathrm{a}}$ & $4.34^{\mathrm{a}}$ \\
Body conformation & $4.79^{\mathrm{a}}$ & $5.05^{\mathrm{b}}$ & $5.22^{\mathrm{bcd}}$ \\
Mothering ability & $4.78^{\mathrm{a}}$ & $4.71^{\mathrm{abc}}$ & $5.29^{\mathrm{cd}}$ \\
Survival & $4.42^{\mathrm{a}}$ & $4.51^{\mathrm{ab}}$ & $4.47^{\mathrm{a}}$ \\
Fertility & $4.48^{\mathrm{a}}$ & $4.48^{\mathrm{ab}}$ & $4.48^{\mathrm{a}}$ \\
Heat tolerance & $7.38^{\mathrm{b}}$ & $6.73^{\mathrm{d}}$ & $6.87^{\mathrm{d}}$ \\
Disease resistance & $4.20^{\mathrm{a}}$ & $5.14^{\mathrm{bc}}$ & $4.46^{\mathrm{abc}}$ \\
No of offspring & $4.19^{\mathrm{a}}$ & $4.42^{\mathrm{a}}$ & $4.42^{\mathrm{ab}}$ \\
Coat colour & $6.48^{\mathrm{b}}$ & $5.57^{\mathrm{c}}$ & $5.45^{\mathrm{d}}$ \\
Friedman test (chi-square) & 192.64 & 88.48 & 107.08 \\
Asymptotic significance & $\mathrm{P}<0.05$ & $\mathrm{P}<0.05$ & $\mathrm{P}<0.05$ \\
\hline
\end{tabular}

Means in columns followed by different lower case letters are different at the Bonferroni adjusted significance level $\mathrm{p} \leq 0.007$ (Friedman test followed by Wilcoxon signed-rank post hoc tests with Bonferroni's correction for multiple comparisons)

*The lower the mean rank, the more important the trait

Choice of production traits within States The choice of production traits revealed that cultural value was least ranked $(5.12,4.32$ and 5.55, respectively) in Nasarawa, Benue and Plateau States (Table 6).

Table 6: Mean ranks of preferences for production traits and their significant level according to Friedman test*

\begin{tabular}{llll}
\hline Traits & $\begin{array}{l}\text { Nasarawa } \\
\text { Mean rank }\end{array}$ & $\begin{array}{l}\text { Benue } \\
\text { Mean rank }\end{array}$ & $\begin{array}{l}\text { Plateau } \\
\text { Mean rank }\end{array}$ \\
\hline Body size & $3.72^{\mathrm{a}}$ & $3.75^{\mathrm{ab}}$ & $3.69^{\mathrm{a}}$ \\
Growth & $3.88^{\mathrm{a}}$ & $4.14^{\mathrm{ab}}$ & $3.80^{\mathrm{a}}$ \\
Cultural & $5.12^{\mathrm{b}}$ & $4.32^{\mathrm{b}}$ & $5.55^{\mathrm{b}}$ \\
Survival & $3.98^{\mathrm{a}}$ & $3.98^{\mathrm{ab}}$ & $3.72^{\mathrm{a}}$ \\
Fertility & $3.78^{\mathrm{a}}$ & $3.85^{\mathrm{ab}}$ & $3.65^{\mathrm{a}}$ \\
Disease resistance & $3.92^{\mathrm{a}}$ & $4.26^{\mathrm{ab}}$ & $3.88^{\mathrm{a}}$ \\
No of offspring & $3.60^{\mathrm{a}}$ & $3.70^{\mathrm{a}}$ & $3.72^{\mathrm{a}}$ \\
Friedman test (chi-square) & 69.35 & 13.601 & 128.57 \\
Asymptotic significance & $\mathrm{P}<0.05$ & $\mathrm{P}<0.05$ & $\mathrm{P}<0.05$ \\
\hline
\end{tabular}

Means in columns followed by different lower case letters are different at the Bonferroni -adjusted significance level $\mathrm{p} \leq 0.006$ (Friedman test followed by Wilcoxon sigramk post hoc tests with Bonferroni's correction for multiple comparisons)

*The lower the mean rank, the more important the trait 
Preference for breeding traits across the three States

Among all the breeding traits across the three States, only disease resistance varied
$(\mathrm{P}<0.01)$; and this was highly rated in Nasarawa and Plateau compared to Benue State (Table 7).

Table 7: Mean ranks of factors preferred in the choice of breeding stock of goats and their significant level according to Kruskall-Wallis test ${ }^{y}$

\begin{tabular}{|c|c|c|c|c|c|}
\hline Traits & $\begin{array}{l}\text { Nasarawa } \\
\text { Mean rank }\end{array}$ & $\begin{array}{l}\text { Benue } \\
\text { Mean } \\
\text { rank }\end{array}$ & $\begin{array}{l}\text { Plateau } \\
\text { Mean rank }\end{array}$ & Kruskall-Wallis test & Asymptotic significance \\
\hline Body size & 89.50 & 91.00 & 91.00 & 0.154 & $0.926^{\mathrm{ns}}$ \\
\hline Body conformation & 86.58 & 89.68 & 95.24 & 1.713 & $0.425^{\mathrm{ns}}$ \\
\hline Mothering ability & 87.74 & 86.94 & 96.82 & 2.933 & $0.231^{\mathrm{ns}}$ \\
\hline Survival & 90.40 & 89.22 & 91.88 & 0.292 & $0.864^{\mathrm{ns}}$ \\
\hline Fertility & 90.11 & 89.95 & 91.44 & 0.105 & $0.949^{\text {ns }}$ \\
\hline Heat tolerance & 90.97 & 81.88 & 98.66 & 3.623 & $0.163^{\text {ns }}$ \\
\hline Disease resistance & $83.75^{\mathrm{a}}$ & $100.62^{b}$ & $87.13^{\mathrm{a}}$ & 10.888 & $0.004 * *$ \\
\hline No of offspring & 88.48 & 91.46 & 91.57 & 0.677 & $0.713^{\mathrm{ns}}$ \\
\hline Coat colour & 101.10 & 84.60 & 85.80 & 4.989 & $0.083^{\mathrm{ns}}$ \\
\hline 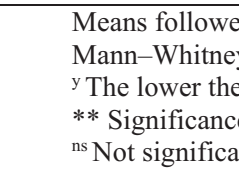 & $\begin{array}{l}\text { by different } \mathrm{u} \\
\mathrm{J} \text { tests }(\mathrm{P} \leq \\
\text { hean rank, the } \\
\mathrm{P} \leq 0.01\end{array}$ & $\begin{array}{l}\text { ercase le } \\
05)] \text {. } \\
\text { ore impo }\end{array}$ & $\begin{array}{l}\text { n rows are } d \\
\text { the trait }\end{array}$ & ent [Kruskall & test followed by \\
\hline
\end{tabular}

Preference for production traits across the three States

Across the three States, disease resistance, survival, fertility, number of offspring and body size appeared similar $(\mathrm{P}>0.05)$ as preference for production traits (Table 8). However, growth (Plateau State) and cultural importance (Benue State) varied across the States $(\mathrm{P}<0.05$ and $\mathrm{P}<0.01$, respectively).

Table 8: Mean ranks of preferences for production traits and their significant level according to Kruskall-Wallis test ${ }^{\mathrm{y}}$

\begin{tabular}{llllll}
\hline Traits & $\begin{array}{l}\text { Nasarawa } \\
\text { Mean rank }\end{array}$ & $\begin{array}{l}\text { Benue } \\
\text { Mean } \\
\text { rank }\end{array}$ & $\begin{array}{l}\text { Plateau } \\
\text { Mean rank }\end{array}$ & Kruskall-Wallis test & Asymptotic significance \\
\hline Body size & 90.00 & 93.00 & 88.50 & 1.154 & 0.561 \\
Growth & $90.30^{\mathrm{a}}$ & $97.68^{\mathrm{b}}$ & $83.52^{\mathrm{a}}$ & 6.371 & $0.041^{*}$ \\
Cultural & $91.52^{\mathrm{b}}$ & $75.28^{\mathrm{a}}$ & $104.70^{\mathrm{b}}$ & 12.277 & $0.002^{* *}$ \\
Survival & 92.26 & 94.84 & 84.40 & 4.218 & 0.121 \\
Fertility & 90.58 & 94.93 & 85.98 & 3.861 & 0.145 \\
Disease resistance & 88.44 & 98.08 & 84.98 & 5.467 & 0.065 \\
No of offspring & 88.50 & 93.00 & 90.00 & 1.474 & 0.479 \\
\hline
\end{tabular}

Means followed by different uppercase letters in rows are different [Kruskall -Wallis test followed by

Mann-Whitney U tests]. ${ }^{\mathrm{y}}$ The lower the mean rank, the more important the trait

$*$, ** Significance at $\mathrm{P} \leq 0.05$ and $\mathrm{P} \leq 0.01$, respectively ${ }^{\text {ns }}$ Not significant

\section{Discussion}

The higher number of male respondents in this study is congruous to the submission of Chah et al. (2013). Similarly, Nampanzira et al. (2015) reported that the Ownership $(65 \%)$ of goats was the responsibility of men. The present finding on marital status is also consistent with the report of Nampanzira et al. (2015) that majority of the households keeping goats were married. The educational status revealed that the literacy level of majority of the farmers is low which could affect their production level. It has been argued that access to 
education is related to the capacity of farmers to use appropriate information and skills for the development of their agricultural enterprise with concomitant effect on income generation (Adeleye et al., 2016). The very low number of farmers with access to credit may not be unconnected with the high poverty rate at the rural level. This is not surprising because the National Bureau of Statistics (NBS) (2010) put at 68\% the rural poverty rate in Nigeria. Most of these farmers were resource poor, hence relatively low farming inputs (savings inclusive). This could have also negatively affected the scale of production. In a related study, Okewu and Iheanacho (2015) reported inadequate credit facilities as a bane in goat business. Most of the goat keepers were within the active working age group. Household labour is an essential resource that influences management practices, enterprise combinations, labour hiring/sharing strategies and overall levels of technical and economic performance (ILCA, 1990). The present finding is consistent with the report of Dossa et al. (2008) where younger household members were more likely to own small ruminants. Adams and Ohene-Yankyera (2014) also reported farmers' average age of $47.29 \pm 16.00$ years. However, it is contrary to the submission of Adesehinwa et al. (2004) in south west Nigeria where most of the farmers are within the age range of 51 to 60 years. It is possible that the rural farmers in the present study were facing the reality of non-availability of white collar jobs which could have probably reduced ruralurban migration of the active men and women. The average household size of this study agrees with the between 6 and 8 family members reported by Adewumi et al. (2015). This is an indication of availability of more labour resources that could be drafted to goat production.

Most of the goat producers kept stock largely to generate additional money for livelihood. The variation across states may be due to socio-economic and cultural differences. This is consistent with the findings of Dossa et al. (2015). The flock structure revealed the preponderance of WAD goats in the three study areas. This is similar to the findings of Ajayi et al. (2007). The average flock sizes in the present study are comparable to the values of 8.8 and 7.8 heads for goats reported for Kano (Nigeria) and Bobo Dioulasso (Burkina Faso) (Dossa et al., 2015). They are however lower than the value of 13.9 obtained in Ethiopian goats (Asefa et al., 2015) and an average of 13.0 reported for goats kept by rural small holder farmers in the semi-arid regions of Uganda (Nampanzira et al., 2015).

Most of the foundation stocks were purchased from the markets and neighbourhoods indicating these two sources as being important in establishing the breeding stock. The semi-intensive management system mostly adopted by the farmers is contrary to the intensive (Chah et al., 2013) and extensive system reported by Oseni and Ajayi (2014). This may be due to ecological differences and prevailing resources in the study areas. The high contact of households in Benue and Plateau to health officials may be due to their willingness to pay for veterinary services. This is an indication that great potential exist in these areas to address health related challenges and probably adopt innovations. As farmers have more contacts with veterinarians, their likelihood of being medium and high level adopters increases (Boz, 2015). The productivity indices revealed the extent of twinning in goats kept by farmers in Nasarawa, Benue and Plateau States. With respect to West African Dwarf, Oseni and Ajayi (2014) reported that this 
breed of goats is renowned for its adaptation to hot and humid environments, high fertility and prolificacy under backyard systems.

Body size, fertility and number of offspring were more consistent for selection purpose in the study areas. Duguma et al. (2010) reported that body traits including size are important criteria of selection under traditional livestock breeding practices while Akpa et al. (2006) submitted that parity and litter size of does were major determinants of the herd structure for breeding does. In their own findings, Nandolo et al. (2016) reported body size and twinning as important traits for withinbreed selection as a tool for sustainable goat improvement in Malawi. In a related study, however, development and conformation were the first criteria used for choosing animals (Alexandre et al., 2009). Selection of good quality breeding stock is an essential component for high productivity (Chah et al., 2013). Therefore, the development of a breeding goal for improvement of indigenous stock should, according to Okeno et al. (2011), focus on the traits perceived important by stakeholders. This is because when breeding goals are developed without considering the needs of all the stakeholders, there are high tendencies of their being rejected by end users.

The farmers' preferences for production traits in the flock revealed the importance of all apart from cultural value. It illustrates that given a choice, farmers would prefer goat that produced more offspring (high reproductive performance), more fertile (for procreation), large body size (for meat production) and highly resistant to diseases. The present findings are consistent with the reports of Dossa et al. (2015). Favourable correlation suggests that if major importance is placed on performance traits in stressful environments, adaptability traits would not be compromised and thus the most productive and adapted animals for each environment need to be identified for breeding purposes. At the micro level the definition of breeding objectives means that for the given production environment, the relative importance of improvement of different traits of the breed must be identified (Phillpson, 2011).

\section{Conclusion}

The study revealed that goats play multifunctional roles in all the study areas. The variation in the production objectives across states may be due to socio-economic and cultural differences. Farmers adopted different criteria for selection of breeding and production traits within and across the States. Breeding strategies and policies targeting goat keepers in the study areas will be more effective when incorporating indigenous knowledge of the traditional choice attributes of goats as a basis for selection criteria in their production systems.

\section{Acknowledgement}

The authors would like to express their appreciation to all the farmers and local enumerators that took part in the field study.

\section{References}

Abdul-Aziz., M. 2010. Present status of the world goat populations and their productivity. Lohman Information, 45: 42-52.

Abegaz, S., Sölkner, J., Gizaw, S., Dessie, T., Haile, A. and Wurzinger, $M$. 2013. Description of production systems and morphological characteristics of Abergelle and Western low-land goat breeds in Ethiopia: implications for community-based breeding 
Assessment of production objective and breeding practices of rural goat keepers and implications for a breeding programme in north central Nigeria

programmes. Animal Genetic

Resources Information, 53: 69-78.

Adams, F. and Ohene-Yankyera, K. 2014. Socio-economic characteristics of subsistent small ruminant farmers in three regions of Northern Ghana. Asian Journal of Applied Science and Engineering, 3: 93106.

Adeleye, O., Alli-Balogun , J. K., Afiemo, O. G. and Bako, S. 2016. Effects of Goat Production on the Livelihood of Women in Igabi, Chikun and Kajuru Local Government Areas, Kaduna State, Nigeria. Asian Journal of Agricultural Extension, Economics \& Sociology, 11: 1-8.

Adesehinwa, A. O. K., Okunola, J. and Adewumi, M. K. 2004. Socioeconomic characteristics of ruminant livestock farmers and their production constraints in some parts of South-western Nigeria. Livestock Research for Rural Development. Vol. 16, Art. \#61. Retrieved October 22, 2016 , f $\quad r \quad$ m http://www.1rrd.org//rrd16/8/ades 16061.htm

Adewumi, O. O., Lawal-Adebowale, $\mathbf{O}$. A. and Adegbemile, D. A. 2015. Assessment of farm families' acceptability of small ruminants' milk for consumption in selected rural communities in Ogun State, Nigeria. Journal of Agricultural Extension and Rural Extension, 7 (4): 135-141.

Ajayi, F. A., Okunsebor, S. A. and Yakubu, A. 2007. Pests and diseases of crops, livestock and fish. In: Akwa, V.L., Binbol, N.L., Samaila, K.I. and Marcus, N.D. (Eds). Geographical perspective on Nasarawa State. $1^{\text {st }}$ edition, Onaivi Printing and Publishing Co. Ltd., Nasarawa State, Nigeria. Pp. $81-89$.

Akpa, G. N., Duru, S. and Bawa, G. S. 2006. The herd structure of breeding does of smallholder red Sokoto goat. Nigerian Journal of Animal Production, 28 (2): 119 122.

Alexandre, G., Leimbacher, F., Maurice, O., Domarin, D., Naves, M. and Mandonnet, N. 2009. Goat farming systems in Martinique: management and breeding strategies. Tropical Animal Health and Production, 41: 635-644.

Asefa, B., Kebede, K. and Effa, K. 2015. Breeding objectives, selection criteria and breeding system of Indigenous goat types in Bale zone, Oromia, Ethiopia. Int. J. Agril. Res. Innov. \& Tech., 5 (2): 715.

Ayalew, W., Rischkowsky, B., King, J.M. and Bruns, E. 2003. Crossbreds did not create more net benefits than indigenous goats in Ethiopian smallholdings. Agric. Sys., 76: 1137- 156.

Boz, I. 2015. Adoption of innovations and best management practices by goat farmers in eastern Mediterranean Region of Turkey. Journal of Agricultural Extension and Rural Development, 7 (7): 229-239.

Chah, J. M., Obi, U. P. and NdoforFoleng, H. M. 2013. Management practices and perceived training needs of small ruminant farmers in Anambra State, Nigeria. African Journal of Agricultural Research, 8(22): 2713-2721.

Dossa, L. H., Sangaré, M., Buerkert, A. 
and Schlecht, E. 2015 . Production objectives and breeding practices of urban goat and sheep keepers in West Africa: regional analysis and implications for the development of supportive breeding programs. SpringerPlus, $4: 281$.

Dossa, L. H., Rischkowsky, B., Birner, R. and Wolly, C. 2008. Socioeconomic determinants of keeping goats and sheep by rural people in southern Benin. Agric. Hum. Values, 25: 581-592.

Duguma, G., Mirkena, T., Haile, A., Iñiguez, L., Okeyo, A. M., Tibbo M., Rischkowsky, B., Sölkner, J. and Wurzinger, M., 2010. Participatory approaches to investigate breeding objectives of livestock keepers. Livestock Research for Rural Development, 22 (64).

FAOSTAT. 2011. Food and Agricultural Organization of the United $\mathrm{N}$ a $\mathrm{t}$ i $\quad \mathrm{o} \quad \mathrm{n} \quad \mathrm{s}$. http://faostat.fao.org/default.aspx (19. Jul. 2011)

Gizaw, S., Komen, H., Van Arendonk, J. A. M. 2009. Optimal village breeding schemes under smallholder sheep farming systems. Livestock Science, 124: 82-88.

Haile, A., Wurzinger, M., Mueller, J., Mirkena, T., Duguma, D., Mwai, M ., S ö l k n e r, J . a n d Rischkowsky, R. 2011 . Guidelines for Setting up Community-based Sheep Breeding Programs in Ethiopia. ICARDA - tools and guidelines No.1.Aleppo, Syria, ICARDA.

ILCA (International Livestock Centre for Africa). 1990. Livestock systems research manual. Working Paper 1, Vol. 1. ILCA, Addis Ababa, Ethiopia. 287 pp.

Lyam, A. (2000). Nasarawa State. In: [Mamman, A.B., Oyebanji, J.O. and Peters, S.W. (eds)], Nigeria: A People United, a Future Assured. Survey of States, Vol. 2(2), Federal Ministry of Information, Abuja.

Nampanzira, D. K., Kabasa, J. D., Nalule, S.A., Nakalembe, I. and Tabuti, J. R. S. 2015. Characterization of the goat feeding system among rural small holder farmers in the semi-arid regions of Uganda. SpringerPlus, 4:188, DOI: 10.1186/s40064015-0961-3.

Nandolo, W., Wurzinger, M., Mészáros, G., Tassell, C.V., Gondwe, T., Mulindwa, H., Lamuno, D. and Sölkner, S. 2016. Communitybased goat breeding programs in Malawi: set-up and first

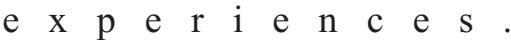
http://www.tropentag.de/2016/ab stracts/links/ Wur zinger_Z2NG UfHg.pdf

National Bureau of Statistics. 2010. Nigerian Poverty Assessment. National Bureau of Statistics (NBS), Abuja.

Okeno, T. O., Kahi, A. K. and Peters, K. J. 2011. Breed selection practices and traits of economic importance for indigenous chicken in Kenya. Livestock Research for Rural Development. Volume 23, Article \#209. Retrieved September 4, $\begin{array}{llllll}2 & 0 & 1 & 2\end{array}, \quad \mathrm{f} \mathrm{r}$ o $\mathrm{m}$ http://www.1rrd.org/lrrd23/10/ok en23209.htm.

Okewu, J. and Iheanacho, A. C. 2015. Socio-economic characteristics 
Assessment of production objective and breeding practices of rural goat keepers and implications for a breeding programme in north central Nigeria

of goat marketers in Benue State, Nigeria. ARC Journal of Social Sciences and Humanities, 1: 5456.

Oseni, S. O. and Ajayi, B. A. 2014. Phenotypic characterization and strategies for genetic improvement of WAD goats under backyard systems. Open Journal of Animal Sciences, 4: 253-262.

Otuma, M. O. 2003. Genetics and Cytological Evaluation of Nigerian ecobreed goats for reproductive capabilities. A. Ph.D thesis Department of Animal Science and Fisheries, Enugu State University of Science and Technology, Abakaliki Campus

Philipson, J. Rege, J. E. O, Zonabend, E. and Okeyo, A. M. 2011. Sustainable breeding programs for tropical farming systems In: Animal Genetics Training resource, version 3, 2011. Ojange, J.M. Magmfors, B. and Okeyo, M.(Eds). International Livestock Research Institute, Nairobi, Kenya, and Swedish University of Agricultural Sciences, Uppsala, $\mathrm{S} \quad \mathrm{w}$ e d e $\mathrm{n}$. http://cgspace.cgiar.org/bitstream handle/10568/3971/Module3.pd f

SPSS. 2010. Statistical Package for Social Sciences. SPSS Inc., 444 Michigan Avenue, Chicago,
IL60611.

Tsegahun, A., Lemma, S., Ameha, S., Abebe, M., Zinash, S. 2000. National goat research strategy in Ethiopia. In: Merkel, R .C., Abebe, G. \& Goetsch, A. L. (eds) The Opportunities and Challenges of Enhancing Goat Production in East Africa. Proceedings of a conference held at Debub University, Awassa, Ethiopia, November 10-12, 2000. E (Kika) de la Garza Institute for Goat Research, Langston University, Langston, OK 1-5.

Yakubu, A., Salako, A. E., Imumorin, I. G., Ige, A. O. and Akinyemi, $M$. O. 2010. Discriminant analysis of morphometric differentiation in the West African Dwarf and Red Sokoto goats. South African Journal of Animal Science, 40 (4): 381-387.

Yakubu, A., Salako, A. E., and I mu morin, I. G. 2011 . Comparative multivariate analysis of biometric traits of West African Dwarf and Red Sokoto goats. Tropical Animal Health and Production, 43: 561566.

Received: $3^{\text {rd }}$ November, 2016 Accepted: $12^{\text {th }}$ February, 2017 